\title{
Performance Analysis of Data Transmission on a Wireless Sensor Network Using the XBee Pro Series 2B RF Module
}

\author{
I Gusti Made Ngurah Desnanjaya*1 I Nyoman Buda Hartawan ${ }^{2}$, Wayan Gede Suka \\ parwita $^{3}$, Ida Bagus Ary Indra Iswara ${ }^{4}$ \\ ${ }_{1,2,3,4}$ STMIK STIKOM Indonesia, Indonesia \\ e-mail : 1* ngurah.desnanjaya@gmail.com, ${ }^{2}$ buda.hartawan@gmail.com, \\ 3ede.suka@gmail.com, ${ }^{4}$ gusari@stiki.indonesia.ac.id
}

\begin{abstract}
Abstrak
Wireless Sensor Network (WSN) merupakan teknologi jaringan nirkabel yang memungkinkan melakukan pemindaian, serta digunakan dalam monitoring kondisi lingkungan, baik yang berada didalam ruangan maupun di luar ruangan. Salah satu perangkat yang digunakan dalam komunikasi data pada WSN adalah Xbee. Xbee merupakan salah satu perangkat pada WSN yang menggunakan frekuensi radio sebagai jalur pengiriman data dari satu perangkat ke perangkat lainya. Dalam melakukan pengiriman data, Xbee dapat dipengaruhi oleh jarak dan kekuatan sinyal antar perangkat. Pada penelitian ini dilakukan analisis jarak komunikasi Xbee di luar ruangan dan di dalam ruangan sehingga mendapatkan data berupa rentan jarak maksimum dari Xbee. Hasil dari penenilitian ini menunjukan bahwa perangkat Xbee Pro Series $2 B$ yang dilakukan pengukuran di luar ruangan mampu melakukan pengiriman data hingga jarak 110 meter, sedangkan perangkat Xbee Pro Series $2 B$ yang dilakukan pengukuran di dalam ruangan mampu melakukan pengiriman data hingga jarak 20 meter.
\end{abstract}

Kata kunci-RSSI, WSN, XCTU, XBee, ZigBee

\begin{abstract}
Wireless Sensor Network (WSN) is a wireless network technology that is capable of scanning and can be used to monitor environmental conditions, both indoors and outdoors. One of the devices used in data communication at WSN is XBee. XBee is a device in WSN that uses radio frequency as a data transmission path from one device to another. In sending data, Xbee can be affected by the distance and signal strength between devices. In this research, Xbee communication distance analysis is done outdoors and indoors so as to get data in the form of maximum distance vulnerable from Xbee. The results of this study indicate that the Xbee Pro Series $2 B$ that is measured outside the room is capable of sending data up to a distance of 110 meters, while the Xbee Pro Series $2 B$ device that is measured indoors is capable of sending data up to a distance of 20 meters.
\end{abstract}

Keywords-RSSI, WSN, XCTU, XBee, ZigBee.

\section{INTRODUCTION}

Environment conditions monitoring can be used to determine factors that affect objects or living things. This factors are changes in temperature, humidity, rainfall, toxic gases, fires, buildings cracks/slopes, and other environmental conditions. There are electronic sensors to 
detect most of the factors. Sensors generate data that will be processed in the processing unit [1][2][3]. But before processing, data need to be transmited on the network to the based station. One of technology that can be used for data transmission in environment conditions monitoring is Wireless Sensor Network (WSN) [4] [5] [6] [7].

WSN generally uses a Wireless Personal Area Network (WPAN) or Low Power Wide Area Network (LPWAN) to transmit data to a based station. The standard for WSN is IEEE 802.15.4, ZigBee, and Bluetooth protocols [8][9][10][11]. One of the devices that support the standart is XBee, which uses radio frequency as a data transmission path from one node to another [10][12][13]. Besides being used as a data transmission device in WSN, XBee also used as data transmission in robot control systems [14][15][16]. As a wireless data transmission device, XBee's performance can be affected by the distance and obstacles between the nodes. There is a research about performance analysis in various environments using ZigBee based wireless sensor networks. In the research, each sensor node is developed from an arduino based microcontroller and Xbee wireless module based on Zigbee/IEEE 802.15.4 standards. The study found an increase in baud rate also increases throughput and decreases packet delay in line of sight (LOS) condition [17][18]. Whereas in comparison of the performance of multihop communication networks and direct communication shows that the performance of multi-hop networks has decreased compared to direct transmission in terms of data throughput and packet delay [19][20][21][22]. In the other research about WSN indoor performance evaluation using Zigbee protocol shows that recommended transmission distance using XBee is 10 meters and the recommended network is a mesh topology [23][24][25][26].

The importance of data transmission in WSN causes the need for reliable communication devices to transmit data. Therefore it is necessary to analyze the communication of XBee, so optimal node distance for data transmission can be found. The results of this study used as a consideration in choosing a communication device on a wireless sensor network or wireless-based remote control system. There are differences in the XBee transmission quality indoors and outdoors. This research contributes to finding out the quality of XBee based transmission indoor and outdoor. So it is used as a consideration in determining the best communication model, based on wireless sensor networks for remote control systems and data transmission. This study conducted a XBee performance analysis in indoor and outdoor environment with and without concrete obstacle. The device is XBee Pro Series 2B with the ZigBee protocol. This study not only tested the LOS and non line of sight (NLOS) conditions, but also measured the effect of moving obstacle on data transmission. In addition, this study conducted the impact of increased data packets on XBee transmission quality. The parameters were packet delay, distance, and Received Signal Strength Indicator (RSSI). Measurements were conducted using XCTU application to make it easy to set-up, configure and test XBee RF modules. XCTU application was used to test wireless network performance in previous study[27] [28] [29] [30].

\section{METHODS}

This research is an experimental study by measuring the XBee performance as a data communication device on WSN. The topology used in this study is point-to-point. Testing conducted indoor and outdoor to measure the quality of data transmission on the XBee. One of the XBee devices is configured as a coordinator node, and the other is configured as an end node. The devices communicate and transmit data via wireless network using the XCTU application. The end device is placed at a predetermined distance from the coordinator and then transmits the data. Measurements of packet delay, distance, and RSSI parameters are carried out to determine the quality of data transmission.

IJEIS Vol. 10, No. 2, October 2020 : $211-222$ 


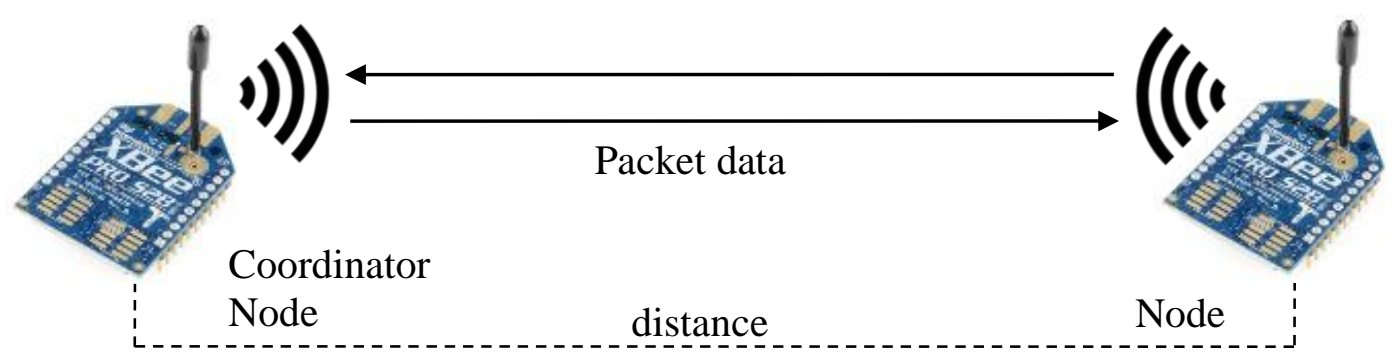

Figure 1 XBee point-to-point topology

Figure 1 is a topology used in XBee data transmission. The coordinator node sends data to the end node and vice versa. Table 1 is the testing environment used in this study.

Table 1 Testing environment

\begin{tabular}{|l|l|l|}
\hline No & Parameter & Specification \\
\hline 1 & XBee & Pro Series 2B \\
\hline 2 & XBee USB Adapter & Keyes Fundiono MD-119 FT232RL \\
\hline 3 & XCTU & Versi 6.4.0 \\
\hline 4 & Packet Payloads & 84 Bytes dan 32 Bytes \\
\hline 5 & Power & $3.3 \mathrm{~V}$ \\
\hline 6 & Number of Packets & 100 \\
\hline 7 & Rx Timeout & $1000 \mathrm{~ms}$ \\
\hline 8 & Tx Interval & $1000 \mathrm{~ms}$ \\
\hline 9 & Baud rate & 9600 \\
\hline 10 & Mode & API \\
\hline 11 & Indoor Testing & Concrete wall divider \\
\hline 12 & Outdoor Testing & Line of Sight (LOS) \\
\hline
\end{tabular}

XCTU used to send data packet with a packet load of 84 Bytes and 32 Bytes in 100 packets. Baud rate used is 9600 with Tx and Rx interval is $1000 \mathrm{~ms}$ using API mode. The test locations are indoors and outdoors. Indoor testing is limited by a concrete wall, while outdoor testing without divider or LOS. Outdoor test is located in a Park with a straight path without obstacle.

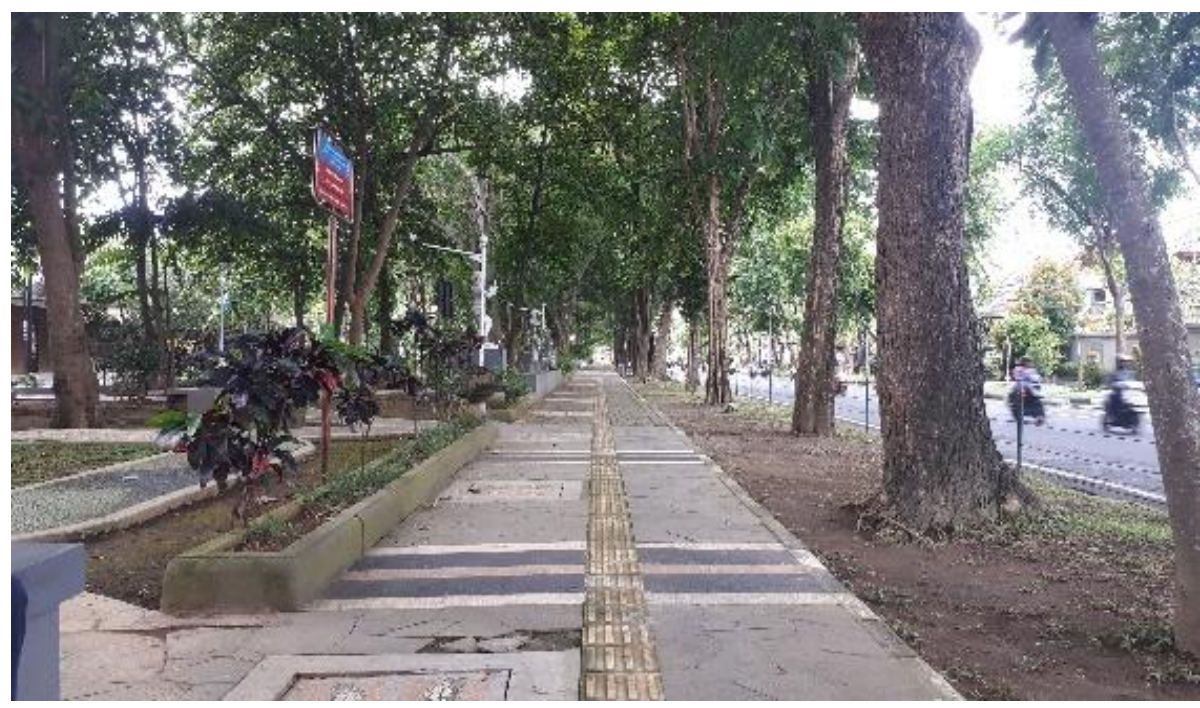

Figure 2 Park for outdoor testing 
Figure 2 shows a path in the park that is used as an outdoor test site. There are trees around the park but they do not obstruct the communication between the XBee. This place was chosen because it has a long straight path and without obstacles, and in the morning the conditions are quiet so it supports the testing. This long straight path meets the requirements for transmission testing with a point-to-point topology. At the time of the test, the weather was sunny. To find out more about the condition of the park for test site, Figure 3 shows the test plan and location.

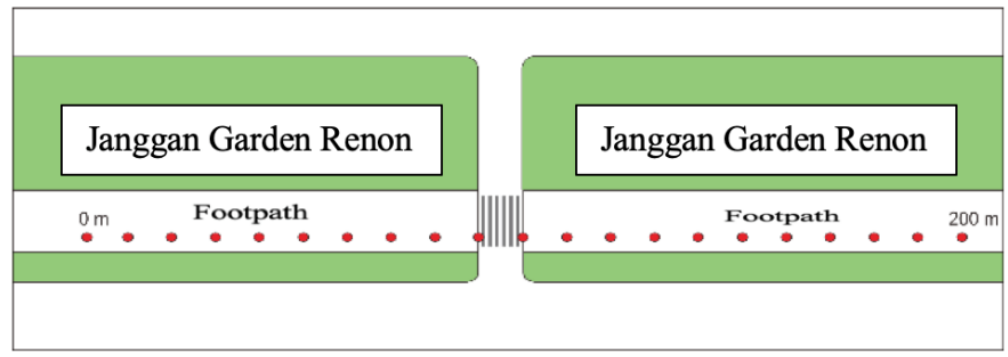

Figure 3 Outdoor testing site plan

The green part at figure 3 is a garden or a gathering place for visitors. The red dots are the distance by 10 meters appart. The 0 meter point or the coordinator node is on the left and the end node which is 200 meters is on the right of the figure. In testing, the XBee Pro Series $2 \mathrm{~B}$ as end node was placed alternately according to the specified distance point. It is starting from 10 meters appart to 200 meters appart from coordinator node. At each point, a test is carried out with 2 type of testing. The first test with 32 bytes packet data transmission and the second with 84 bytes packet data.

The indoor testing is carried out in a residential area by placing the XBee Pro Series 2B as coordinator node inside the house. Figure 4 is the test location in a residential area. XBee Pro Series $2 \mathrm{~B}$ as end node is placed at a predetermined point around the building. There is a house with the same size or type act as an obstacles. The distance used in the residential area test is 40 meters.

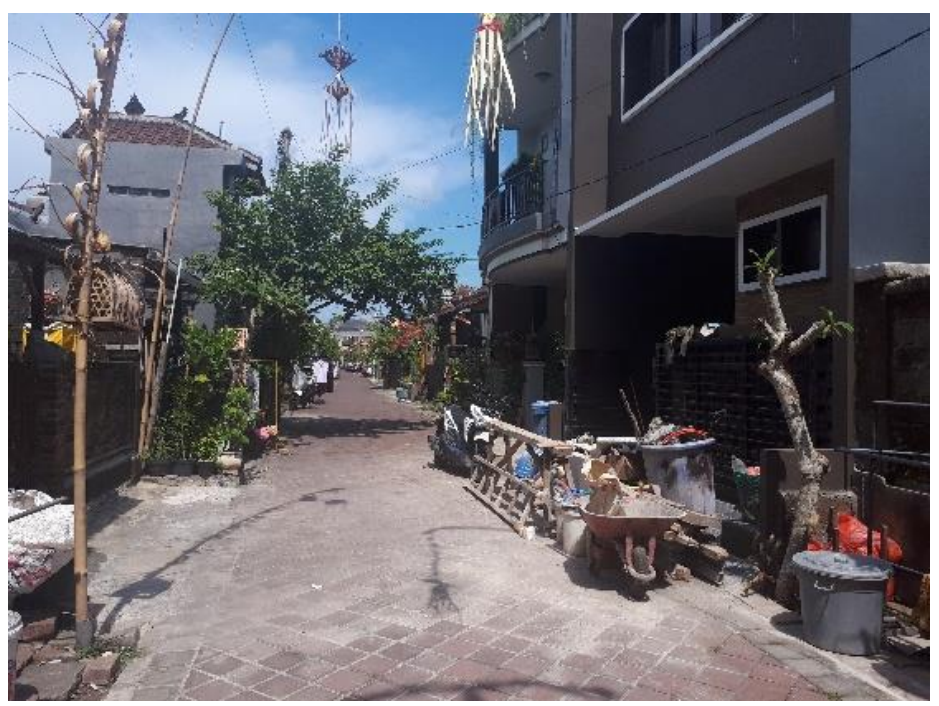

Figure 4 Residential area for indoor testing 


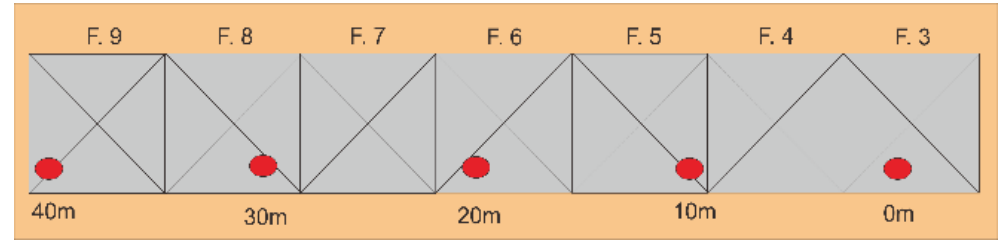

Figure 5 Residential area site plan

Tests were carried out on row of houses with concrete walls. Figure 5 shows a residential area plan that is used as a test site to make it easier to understand the testing environment. The red dots are predetermined points for XBee Pro Series 2B. 0 meters point is located inside the house number F.3 and 40 meters point is located in the house number F.9. The $\mathrm{XBee}$ Pro Series $2 \mathrm{~B}$ as coordinator node is placed in the house number F.3 while the XBee Pro Series $2 \mathrm{~B}$ as end node is placed at the predetermined point inside of each house.

\section{RESULTS AND DISCUSSION}

The test results that have been carried out is presented in table. The parameters measured are distance, packet delay, and RSSI. The distance beetween coordinator node and end node at inside and outside of the room scenario is multiple by 10 meters, which is 10,20 , $30,40,50,60,70,80,90,100$, and 110 meters. The packet data used is 84 Bytes and 32 Bytes and each packet is send 100 times. Table 2 present the packet delay test results.

Table 2 Packet delay average

\begin{tabular}{|c|c|c|c|c|c|c|c|}
\hline \multirow{2}{*}{ Distance $(\mathrm{m})$} & \multicolumn{2}{|c|}{ Outdoor (s) } & \multicolumn{2}{|c|}{ Indoor (s) } & \multirow{2}{*}{ Distance $(\mathrm{m})$} & \multicolumn{2}{|c|}{ Outdoor (s) } \\
\hline & 32 Bytes & 84 Bytes & 32 Bytes & 84 Bytes & & 32 Bytes & 84 Bytes \\
\hline 10 & 1,41 & 1,39 & 1,33 & 1,45 & 110 & 13,20 & 0 \\
\hline 20 & 1,43 & 1,45 & 4,76 & 6,67 & 120 & 0 & 0 \\
\hline 30 & 1,35 & 1,46 & 0 & 0 & 130 & 0 & 0 \\
\hline 40 & 1,40 & 1,33 & 0 & 0 & 140 & 0 & 0 \\
\hline 50 & 1,51 & 1,74 & - & - & 150 & 0 & 0 \\
\hline 60 & 5,26 & 1,56 & - & - & 160 & 0 & 0 \\
\hline 70 & 10,64 & 2,64 & - & - & 170 & 0 & 0 \\
\hline 80 & 2,39 & 1,86 & - & - & 180 & 0 & 0 \\
\hline 90 & 30,28 & 27,39 & - & - & 190 & 0 & 0 \\
\hline 100 & 8,40 & 12,56 & - & - & 200 & 0 & 0 \\
\hline
\end{tabular}

There was no significant increase in the number of packet delay from 10 to 60 meters testing. While there are significant increase at 70 and 90 meters outdoor with 32 bytes data. This happens because there are people and two-wheeled vehicles passing along at the 90 meter. Testing with 84 bytes data at 90 meters have a similar result with 32 bytes data at 90 meters. The maximum test distance that the XBee Pro Series 2B can respond in outdoor is 110 meters for 32 Bytes data and 100 meters for 84 Bytes data. As for indoor testing, there are a huge increase in packet delay at 10 to 20 meters with 32 Bytes and 84 Bytes of data. The XBee Pro Series $2 \mathrm{~B}$ is not responding at 30 meters or more testing distance. Figure 6 is a graph of the average result of the Packet Delay parameter with 32 Bytes and 84 Bytes data indoor and outdoor scenario. 


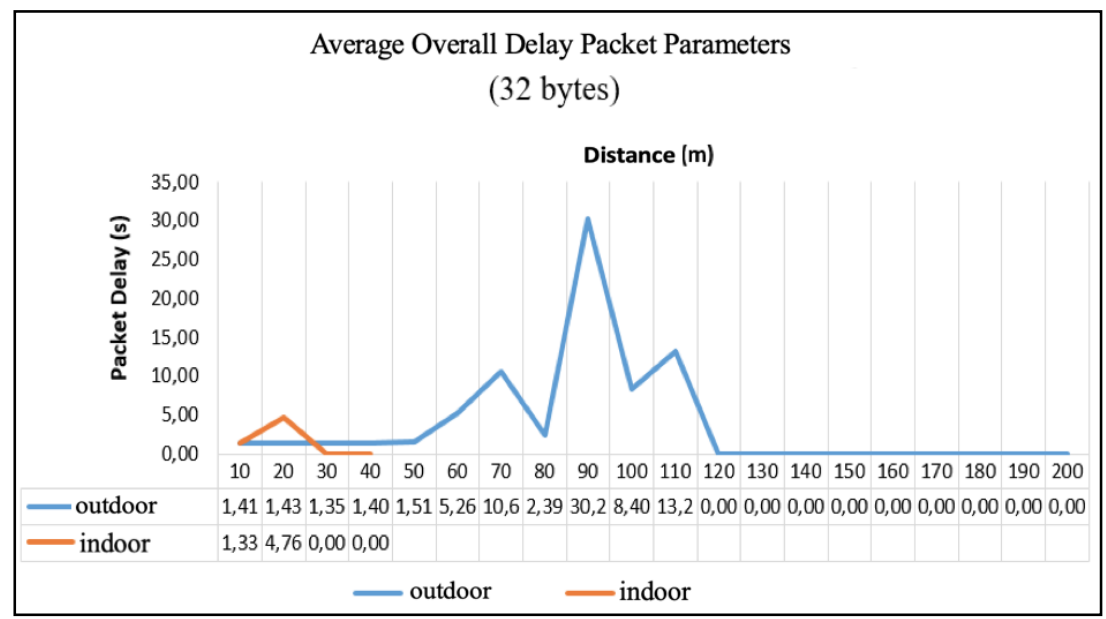

Figure 6 Graph of packet delay with 32 bytes packet data

Figure 6 show average result of packet delay with 32 bytes packet data. Blue line is for outdoor testing result while indoors testing result is marked by an orange line. Outdoor line had a significant increase at the $70,90,100$ and 110 meters distance points. This is due to the existence of objects in the form of people and two-wheeled vehicles passing along at the 70,90, 100 and 110 meters. While the indoor graphic had a slightly spikes at a distance of 20 meters because the house occupants cross the test path at the 20 meter point.

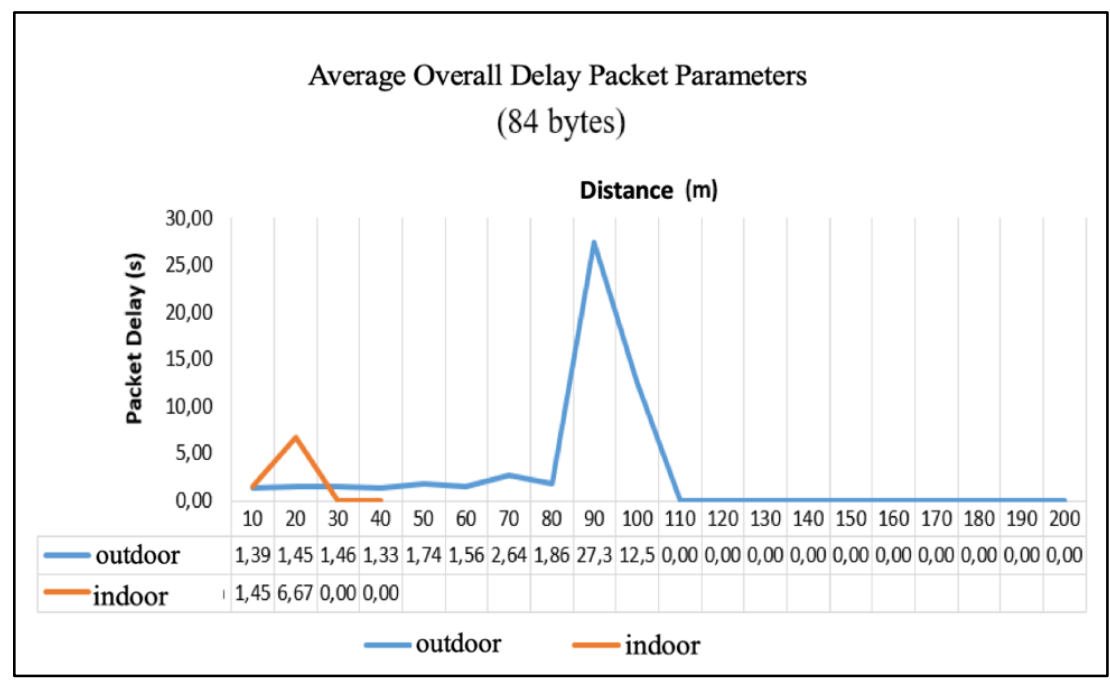

Figure 7 Graph of packet delay with 84 bytes packet data

Figure 7 is a graph of the packet delay parameters testing result with 84 bytes packet data. In the graph, the value of packet delay outdoor is marked by a blue line while indoors is marked by an orange line. The outdoor graphic show a significant spike at the 90 and 100 meter point because there were people and two-wheeled vehicles passing at the 90 and 100 meters point, while the indoor graphics show a slight spike at a distance of 20 meters because the house occupants crossed the test path at 20 meters point.

RSSI measurements are performed when data is transmitted from one node to the another node. The simulation of data transmission is carried out using the XCTU application. RSSI is an indicator used to measure the amount of power/signal received by a wireless device. The stronger the power/signal received by a wireless device, the better the quality of the communication network. The results of RSSI measurements on the Xbee Pro Series 2B are presented in Table 3.

IJEIS Vol. 10, No. 2, October 2020 : $211-222$ 
Table 3 RSII average result

\begin{tabular}{|c|c|c|c|c|c|c|c|}
\hline \multirow{2}{*}{ Distance $(\mathrm{m})$} & \multicolumn{2}{|c|}{ Outdoor $(\mathrm{dBm})$} & \multicolumn{2}{|c|}{ Indoor $(\mathrm{dBm})$} & \multirow{2}{*}{ Distance $(\mathrm{m})$} & \multicolumn{2}{c|}{ Outdoor $(\mathrm{dBm})$} \\
\cline { 2 - 5 } & 32 Bytes & 84 Bytes & 32 Bytes & 84 Bytes & & 32 Bytes & 84 Bytes \\
\hline 10 & -76 & -60 & -70 & -68 & 110 & 0 & 0 \\
\hline 20 & -81 & -61 & -81 & -74 & 120 & 0 & 0 \\
\hline 30 & -76 & -66 & 0 & 0 & 130 & 0 & 0 \\
\hline 40 & -82 & -63 & 0 & 0 & 140 & 0 & 0 \\
\hline 50 & -86 & -73 & - & - & 150 & 0 & 0 \\
\hline 60 & -90 & -70 & - & - & 160 & 0 & 0 \\
\hline 70 & -77 & -73 & - & - & 170 & 0 & 0 \\
\hline 80 & -76 & -73 & - & - & 180 & 0 & 0 \\
\hline 90 & -81 & -54 & - & - & 190 & 0 & 0 \\
\hline 100 & -79 & -75 & - & - & 200 & 0 & 0 \\
\hline
\end{tabular}

Table 3 is the testing result of the RSSI parameters. From the results, it can be seen that the difference between the RSSI result on tests carried outdoor with the 32 bytes and 84 bytes packet data. The difference between 32 bytes to 84 bytes packet data testing is in the range of 2 to 30 point and the difference between the RSSI result on tests carried indoor with 32 bytes to 84 bytes packet data is also different. The difference between 32 bytes and 84 bytes packet data is 8 poin in average. Figure 9 shows a graph of the results of RSSI parameters testing outdoor and indoor with 32 bytes packet data.

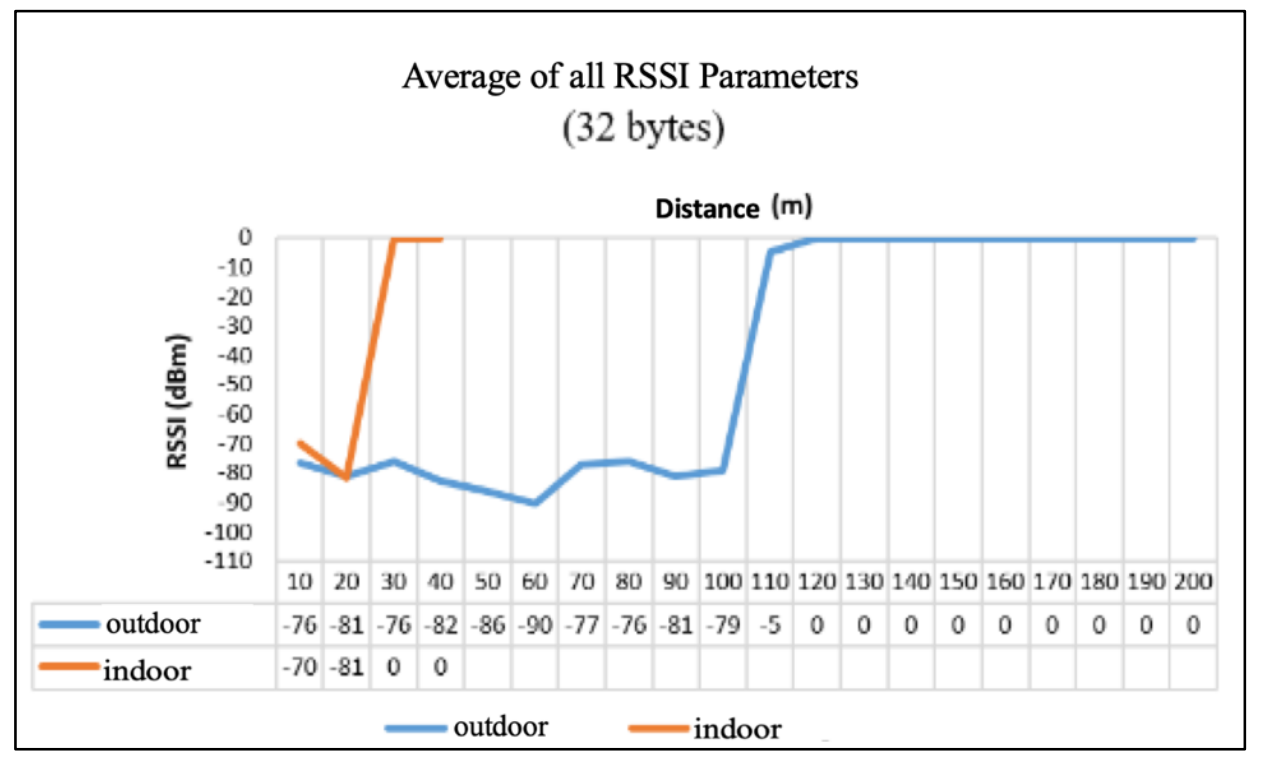

Figure 8 Graph of RSII with 32 bytes packet data

Figure 8 is a graph of the overall testing result for RSSI parameters with 32 bytes packet data. In the graph, the RSSI value outdoor is marked by a blue line while indoors is marked by an orange line. At the 10 meter point the difference between the RSSI outdoor and indoor is 6 poin, while there is no difference at the 20 meter. 


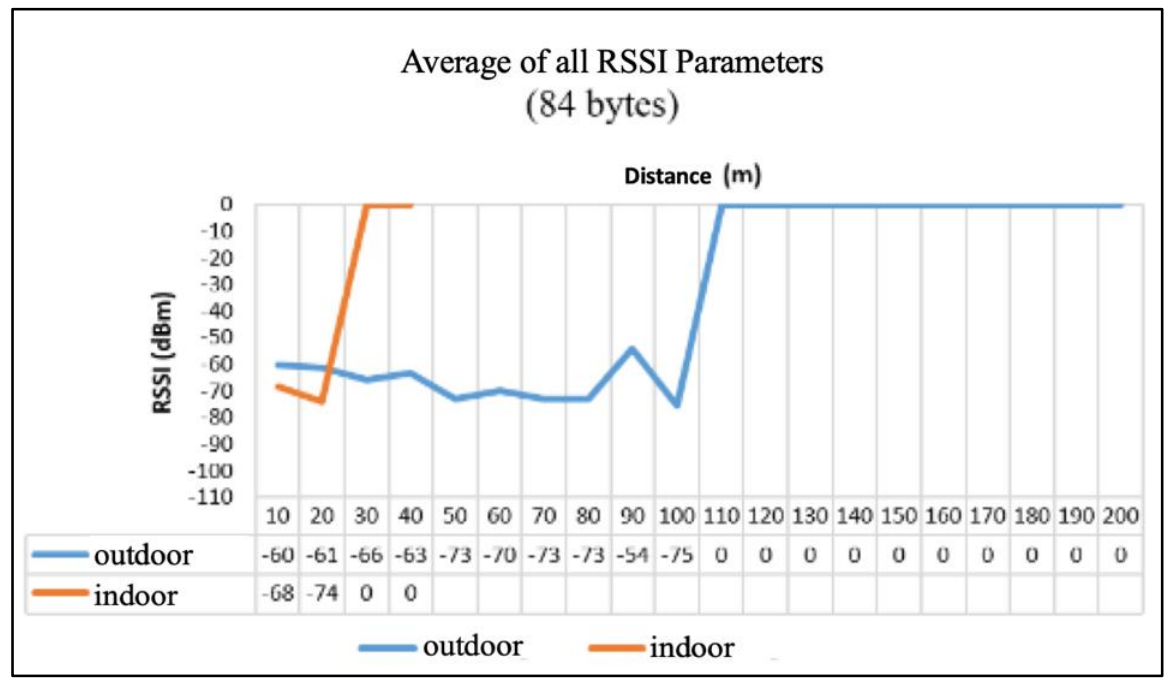

Figure 9 Graph of packet delay with 84 bytes packet data

Figure 9 is a average RSSI parameters graph with a 84 bytes data packet. In the graph, the RSSI outdoor is marked by a blue line while indoors is marked by an orange line. At the 10 meters point the difference between the RSSI outdoor and indoors is 8 point, while at the 20 meter point there is a 13 points difference between the RSSI for outdoor and indoor environtment. At the test location is also measured the success percentage that is the amount of packets that can be received by the end node in units of percent. The test result from testing at a predetermined location is the average result of success percentage parameters using 32 bytes and 84 bytes packet data carried out outdoors and indoors, can be seen in Table 4 . The results show the difference between success percentage in tests carried out outdoors with 32 bytes and 84 bytes data packet.

Table 4 Success percentage average

\begin{tabular}{|c|c|c|c|c|c|c|c|}
\hline \multirow{2}{*}{ Distance $(m)$} & \multicolumn{2}{|c|}{ Outdoor (\%) } & \multicolumn{2}{|c|}{ Indoor $(\%)$} & \multirow{2}{*}{ Distance $(\mathrm{m})$} & \multicolumn{2}{|c|}{ Outdoor (\%) } \\
\hline & 32 Bytes & 84 Bytes & 32 Bytes & 84 Bytes & & 32 Bytes & 84 Bytes \\
\hline 10 & 97,34 & 98,91 & 96,51 & 96,01 & 110 & 0,07 & 0,00 \\
\hline 20 & 95,58 & 98,80 & 43,24 & 34,45 & 120 & 0,00 & 0,00 \\
\hline 30 & 99,22 & 94,48 & 0,00 & 0,00 & 130 & 0,00 & 0,00 \\
\hline 40 & 94,24 & 99,09 & 0,00 & 0,00 & 140 & 0,00 & 0,00 \\
\hline 50 & 88,26 & 78,28 & - & - & 150 & 0,00 & 0,00 \\
\hline 60 & 52,15 & 86,86 & - & - & 160 & 0,00 & 0,00 \\
\hline 70 & 20,41 & 66,65 & - & - & 170 & 0,00 & 0,00 \\
\hline 80 & 72,95 & 69,78 & - & - & 180 & 0,00 & 0,00 \\
\hline 90 & 8,61 & 7,10 & - & - & 190 & 0,00 & 0,00 \\
\hline 100 & 34,56 & 15,27 & - & - & 200 & 0,00 & 0,00 \\
\hline
\end{tabular}

The difference between outdoor environtment is quite significant at the 60, 70, 90, 100 and 110 meter because at the testing there are people and two-wheeled vehicles crossing the test path, thus resulting the data is not fully received by the end node at the 60, 70, 90 and 100 meters points. At a 20 meters distance indoor with 84 bytes packet data, it experienced a significant increase due to the house occupants crossing the test path at a 20 meters point. Figure 10 shows a graph of the average result of the success percentage outdoors and indoors with 32 bytes packet data. The existence of a moving object when the packet is transmitted affects the signal propagation between the Xbee Pro Series 2B that are communicating. Obstacles that occur have an impact on decreasing the quality of packet data delivery. 


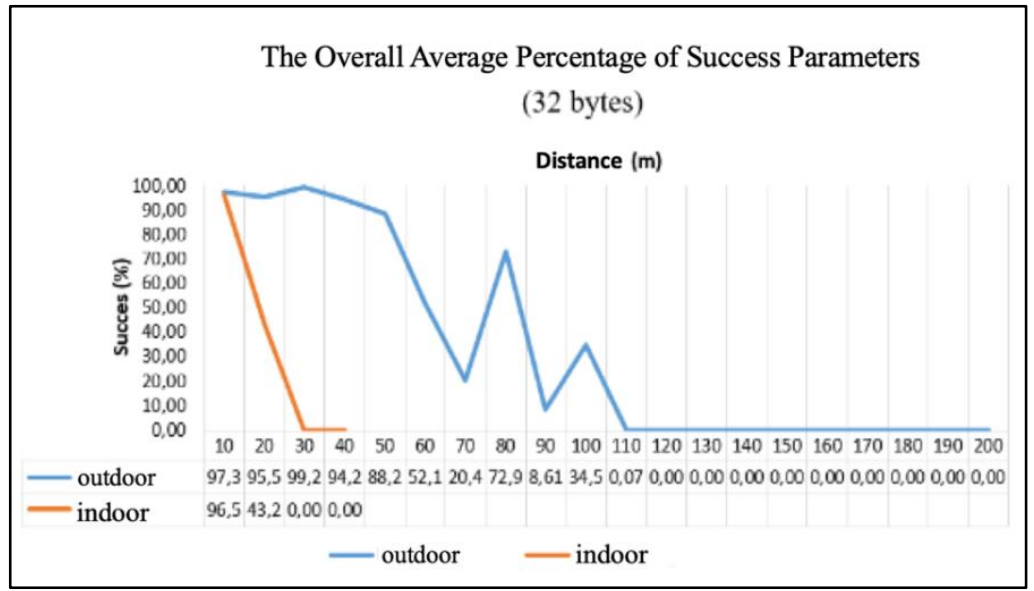

Figure 10 Graph of percentage success with 32 bytes packet data

The graph in figure 10 explained that the success percentage in outdoor testing has a significant difference. At 20 meters distance, the difference between the success percentage rate beetween outdoor and indoor is $50 \%$ due to the house occupants are crossing the test path at 20 meters on indoor testing. At the 70 and 90 meters point, the line on the graph goes down because there are people and two-wheeled vehicles passing and resulting the success percentage rate decreases.

Figure 11 shows the graph of the average results of all parameters from the outdoors and indoors successes percentage with 84 bytes data packet. At 90 meters point there is a $61 \%$ decrease, while at the 20 meters indoors point has decreased by $63 \%$ due to the house occupants crossing the test path. With the whole test results that have been obtained when conducting the testing at a predetermined location, the results of the average overall test using 32 bytes and 84 bytes data packet carried out outdoors and indoors environtment can be seen in Table 5 .

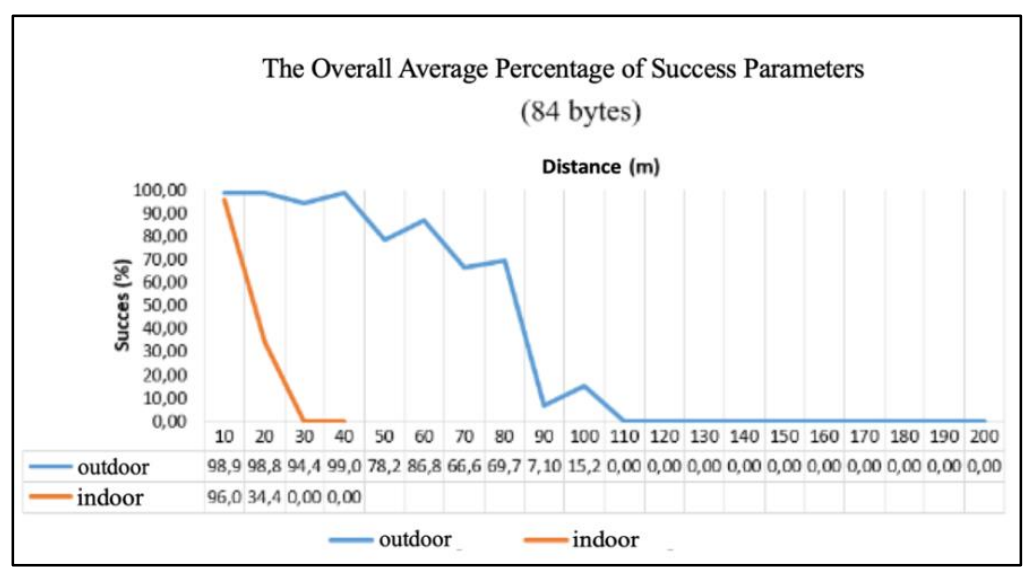

Figure 11 Graph of percentage success with 84 bytes packet data

Table 5 Testing time average

\begin{tabular}{|c|c|c|c|c|c|c|c|}
\hline \multirow{2}{*}{ Distance (m) } & \multicolumn{2}{|c|}{ Outdoor (s) } & \multicolumn{2}{|c|}{ Indoor (s) } & \multirow{2}{*}{ Distance (m) } & \multicolumn{2}{|c|}{ Outdoor (s) } \\
\hline & 32 Bytes & 84 Bytes & 32 Bytes & 84 Bytes & & 32 Bytes & 84 Bytes \\
\hline 10 & 257 & 260 & 256 & 271 & 110 & 215 & 214 \\
\hline 20 & 257 & 269 & 255 & 267 & 120 & 217 & 215 \\
\hline 30 & 267 & 274 & 232 & 235 & 130 & 215 & 217 \\
\hline 40 & 263 & 261 & 230 & 234 & 140 & 214 & 212 \\
\hline 50 & 260 & 265 & - & - & 150 & 217 & 215 \\
\hline 60 & 269 & 253 & - & - & 160 & 217 & 213 \\
\hline 70 & 242 & 259 & - & - & 170 & 213 & 217 \\
\hline 80 & 262 & 264 & - & - & 180 & 219 & 219 \\
\hline 90 & 251 & 227 & - & - & 190 & 221 & 212 \\
\hline 100 & 243 & 240 & - & - & 200 & 218 & 217 \\
\hline
\end{tabular}


Table 5 show the result of the overall test times average. From the results of the average test time with 32 bytes and 84 bytes data packet carried out outdoor and indoors, it can be concluded that the average of all test times with 32 bytes data packet outdoors is 237 seconds or 3 minutes 57 seconds, while for 84 bytes data packet is 236 seconds or 3 minutes 56 seconds. Indoor testing can be concluded that the average of all test times for 32 bytes is 243 seconds or 4 minutes 3 seconds, while for 84 bytes packet data is 252 seconds or 4 minutes 12 seconds.

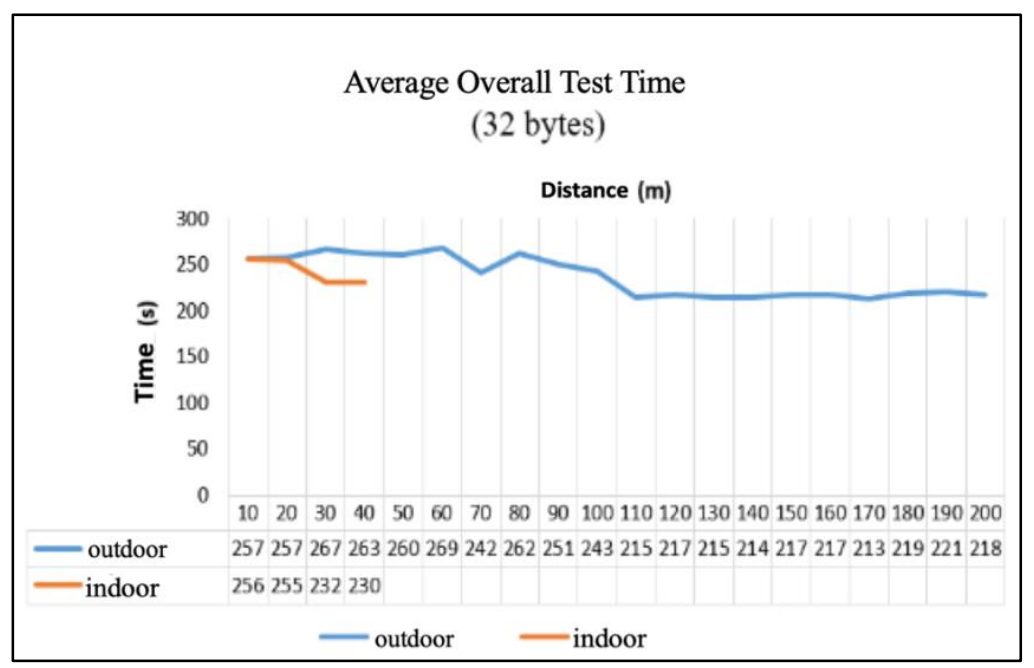

Figure 12 Graph of testing time with 32 bytes packet data

Figure 12 shows a graph of the average overall test time with a total data size of 32 bytes. Based on the data in the chart above, the test time outside is longer than indoors. A very significant difference is at a distance of 30 and 40 meters, which is 30 to 35 seconds.

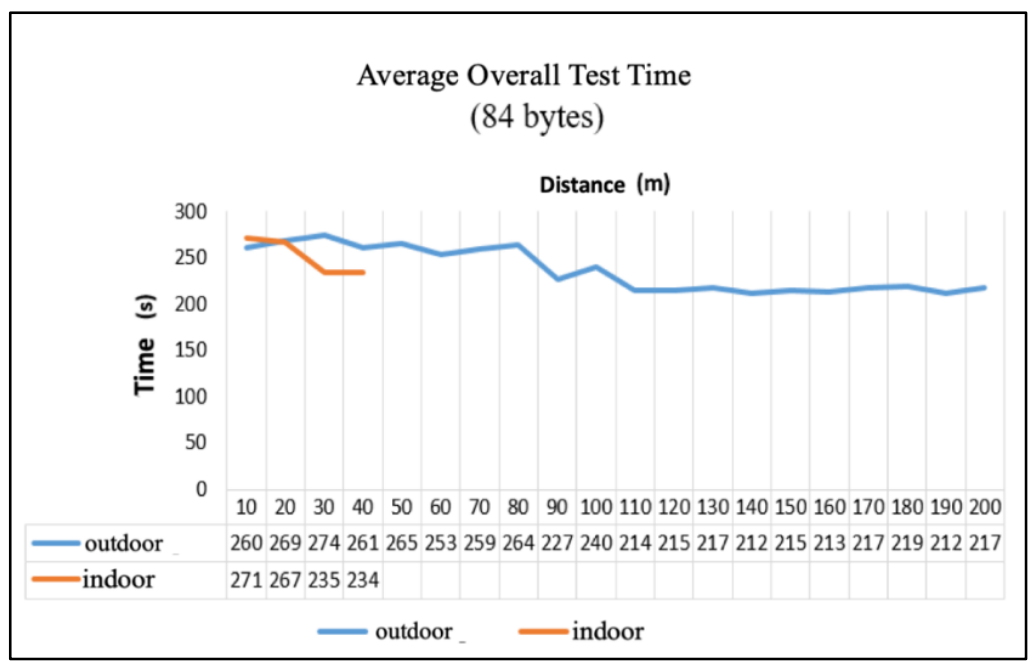

Figure 13 Graph of testing time with 84 bytes packet data

Figure 13 shows a graph of the average overall test time with a total data size of 84 bytes. Based on the data in the chart above, the test time outside the room and indoors has a slight difference. There are differences of 23 to 31 seconds at 30 to 40 meters distance.

\section{CONCLUSIONS}

The conclusions that can be drawn based on the results of this study are as follows:

1. From the research, the XBee Pro Series $2 \mathrm{~B}$ is able to transmit data up to a 110 meters outdoors and 20 meters indoors. The lowest average packet delay obtained in outdoor testing

IJEIS Vol. 10, No. 2, October 2020 : $211-222$ 
is for 32 bytes at 30 meters, and for 84 bytes at 40 meters. As for indoors, the lowest average packet delay reached with 32 Bytes and 84 Bytes packet size at 10 meters distance.

2. Obstacles that exist at the test environtment greatly affect the distance of XBee Pro Series 2B data transmission. In outdoor testing for 32 Bytes, the best received signal strength is obtained at 60 meters and for 84 Bytes at 100 meters. For indoor testing, the best received signal strength recieved with 32 Bytes and 84 Bytes packet data at 20 meters distance.

3. The moving objects that blocking data transmission has an impact on the quality of data transmission. The moving objects that causes obstruction in the process of sending data has an impact on decreasing the quality of XBee Series 2B data transmission.

\section{ACKNOWLEDGEMENTS}

This research has received support from STMIK STIKOM Indonesia through the Institute of Research and Community Service (LPPM), as well as the Institute of Innovation and Creativity Development (LPIK) which has provided research tools and facilities.

\section{REFERENCES}

[1] P. Rycerski, L. M. Candanedo Ibarra, F. Galatoulas, K. N. Genikomsakis, A. Bagheri, and C. S. Ioakimidis, "Field performance analysis of IEEE 802.15.4 XBee for open field and urban environment applications in Smart Districts," in Energy Procedia, 2017.

[2] B. RAHMADYA, M. SISKA, and F. AKBAR, "Ubiquitous Sensor Networks: Efisiensi Sistem Kontrol Cairan Infus Pasien Rawat Inap," ELKOMIKA J. Tek. Energi Elektr. Tek. Telekomun. Tek. Elektron., 2018.

[3] S. Pirbhulal et al., "A novel secure IoT-based smart home automation system using a wireless sensor network," Sensors (Switzerland), 2017.

[4] K. N. M. Kumar, K. Akhi, S. K. Gunti, M. Sai, and P. Reddy, "Implementing Smart Home Using Firebase," Int. J. Res. Eng. Appl. Sci., 2016.

[5] Q. N. Cao, C. Liu, and K. Y. Meng, "Design of oilfield wireless monitoring system based on ZigBee and WiFi," Xi'an Shiyou Daxue Xuebao (Ziran Kexue Ban)/Journal Xi'an Shiyou Univ. Nat. Sci. Ed., 2015.

[6] Y. Zakaria and K. Michael, "An Integrated Cloud-Based Wireless Sensor Network for Monitoring Industrial Wastewater Discharged into Water Sources," Wirel. Sens. Netw., 2017.

[7] F. Ugm, "Rancang Bangun M2M ( Machine-to- Machine) Communication Berbasis 6LoWPAN," vol. 7, no. 1, pp. 93-104, 2017.

[8] K. V. De Oliveira, H. M. Esgalha Castelli, S. Jose Montebeller, and T. G. Prado Avancini, "Wireless Sensor Network for Smart Agriculture using ZigBee Protocol," in 2017 IEEE 1st Summer School on Smart Cities, S3C 2017 - Proceedings, 2018.

[9] M. Pule, A. Yahya, and J. Chuma, "Wireless sensor networks: A survey on monitoring water quality," J. Appl. Res. Technol., 2017.

[10] D. Y. Kim, S. Kim, H. Hassan, and J. H. Park, "Adaptive data rate control in low power wide area networks for long range IoT services," J. Comput. Sci., 2017.

[11] R. A. Salam, M. R. F. Islamy, M. M. Munir, E. Yuliza, Khairurrijal, and M. Irsyam, "Design and implementation of wireless sensor network on Ground movement Detection System," in Proceeding - 2015 International Conference on Computer, Control, Informatics and Its Applications: Emerging Trends in the Era of Internet of Things, IC3INA 2015, 2016.

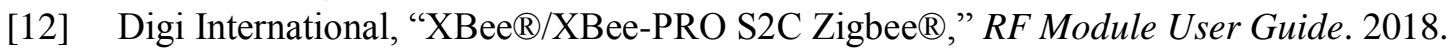

[13] J. Tosi, F. Taffoni, M. Santacatterina, R. Sannino, and D. Formica, "Throughput Analysis of BLE Sensor Network for Motion Tracking of Human Movements," IEEE

Performance Analysis of Data Transmission on a Wireless...(I Gusti Made Ngurah Desnanjaya) 
Sens. J., 2019.

[14] C. Z. Myint, L. Gopal, and Y. L. Aung, "WSN-based reconfigurable water quality monitoring system in IoT environment," in ECTI-CON 2017 - 2017 14th International Conference on Electrical Engineering/Electronics, Computer, Telecommunications and Information Technology, 2017.

[15] Y. Yuliza, "Komunikasi Antar Robot Menggunakan RF Xbee dan Arduino Microcontroller," J. Telekomun. dan Komput., 2017.

[16] M. Z. M Zulfitra and P. Gunoto, "PERANCANGAN SISTEM KENDALI GERAK ROBOT BERODA MENGGUNAKAN XBEE PRO REMOTE," SIGMA Tek., 2018.

[17] M. A. Moridi, Y. Kawamura, M. Sharifzadeh, E. K. Chanda, M. Wagner, and H. Okawa, "Performance analysis of ZigBee network topologies for underground space monitoring and communication systems," Tunn. Undergr. Sp. Technol., 2018.

[18] D. J. Bora, N. Kumar, and R. Dutta, "Implementation of wireless MEMS sensor network for detection of gait events," IET Wirel. Sens. Syst., 2019.

[19] H. Fitriawan, M. Susanto, A. S. Arifin, D. Mausa, and A. Trisanto, "ZigBee based wireless sensor networks and performance analysis in various environments," in $Q i R$ 2017 - 2017 15th International Conference on Quality in Research (QiR): International Symposium on Electrical and Computer Engineering, 2017.

[20] M. Bor and U. Roedig, "LoRa transmission parameter selection," in Proceedings - 2017 13th International Conference on Distributed Computing in Sensor Systems, DCOSS 2017, 2018.

[21] N. Ahmad, A. Hussain, I. Ullah, and B. H. Zaidi, "IOT based wireless sensor network for precision agriculture," in iEECON 2019 - 7th International Electrical Engineering Congress, Proceedings, 2019.

[22] H. C. Lee and H. H. Lin, "Design and Evaluation of an Open-Source Wireless Mesh Networking Module for Environmental Monitoring," IEEE Sens. J., 2016.

[23] R. P. Narayanan, T. V. Sarath, and V. V. Vineeth, "Survey on Motes Used in Wireless Sensor Networks: Performance \&amp; Parametric Analysis," Wirel. Sens. Netw., 2016.

[24] S. Sruthy and S. N. George, "WiFi enabled home security surveillance system using Raspberry Pi and IoT module," in 2017 IEEE International Conference on Signal Processing, Informatics, Communication and Energy Systems, SPICES 2017, 2017.

[25] X. Li and X. Lu, "Design of a ZigBee wireless sensor network node for aquaculture monitoring," in 2016 2nd IEEE International Conference on Computer and Communications, ICCC 2016 - Proceedings, 2017.

[26] Y. Y. Maulana, G. Wiranto, and D. Kurniawan, "Online Monitoring Kualitas Air Pada Budidaya Udang Berbasis WSN Dan IoT," INKOM J. Informatics, Control Syst. Comput., 2016.

[27] I. N. B. Hartawan and I. G. M. N. Desnanjaya, "ANALISIS KINERJA PROTOKOL ZIGBEE DI DALAM DAN DI LUAR RUANGAN SEBAGAI MEDIA KOMUNIKASI DATA PADA WIRELESS SENSOR NETWORK," J. Resist. (Rekayasa Sist. Komputer), 2018.

[28] E. K. Putra and Z. Zaini, "ANALISIS KINERJA PROTOKOL ZIGBEE DENGAN TOPOLOGI STAR PADA BUILDING AUTOMATION SYSTEM (BAS),” $J$. TEKNOIF, 2017.

[29] S. Ikhwan, R. Farrid Christianti, N. Ardilla, and S. Suryadi, "Analisis Quality Of Service Jaringan Mobile Wiseland Menggunakan DIGI-XCTU," J. Nas. Teknol. dan Sist. Inf., 2020.

[30] R. Fitriani, "KAJIAN KEKUATAN SINYAL RADIO (RSSI) XBEE DALAM RANGKA PEMASANGAN LANDSLIDE EARLY WARNING SYSTEM (LEWS) DI KABUPATEN GARUT, TASIKMALAYA DAN MAJALENGKA," J. Alami $J$. Teknol. Reduksi Risiko Bencana, 2019.

IJEIS Vol. 10, No. 2, October 2020 : $211-222$ 